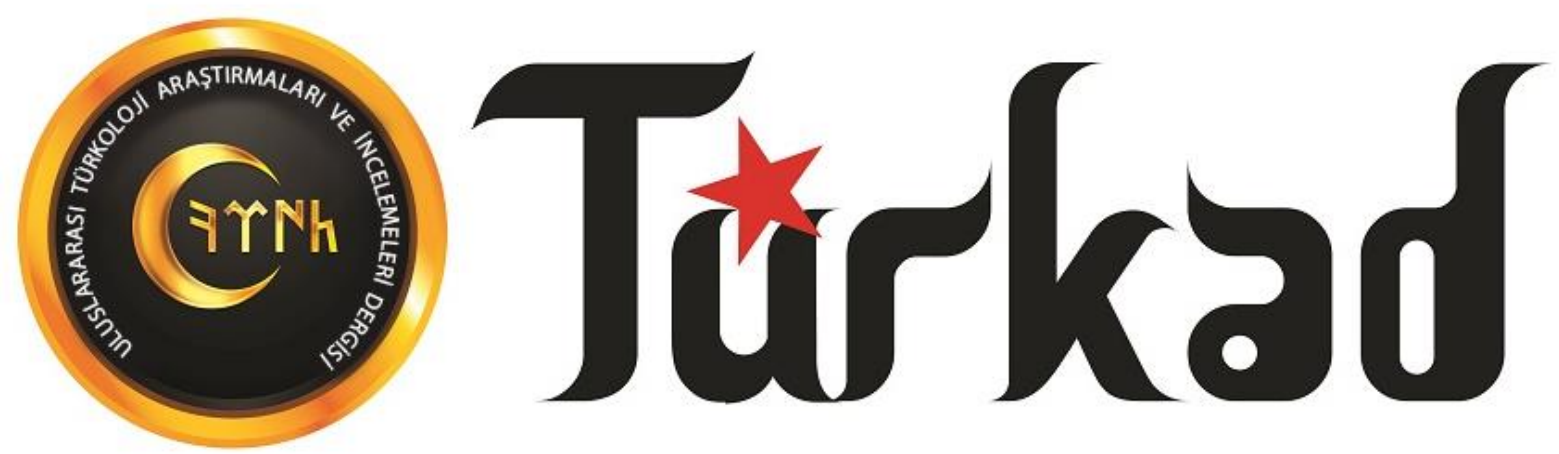

\title{
Hermeneutik ve Nitel Araştırma İlişkisi Üzerine Bir Değerlendirme
}

\author{
İem NAMLI ALTINTAŞ ${ }^{1} \&$ Cemil Can ERDEM ${ }^{2}$
}

\begin{abstract}
Özet
İnsanı ve toplumu esas alan sosyal bilimler, bilimsel boyutta ele alınırken tıpkı doğa bilimleri gibi gözlem, karşılaştırma ve deneyler kullanılarak anlaşılmaya çalışılmış, tinsel etkenler (duygular, metafizik, zeka) yok sayılmıştır. Sosyal bilimlerin yorumsamacı anlatımının yer aldığı bu paradigma bize insanın öznel bir varlık olduğunu dönüşümsel süreçte metodoloji dahil olmak üzere her alanda insanların sosyal bilimlerin doğası ile birlikte hareket ettiğini söyler. Kuramsal çerçevede ele alınan bu çalışmanın amacı hermeneutik yaklaşımın, pozitivist bilim anlayışından farkını ortaya koymaktır. Bu bağlamda yorumsamacı bilim yaklaşımının temelleri ve kısa tarihçesi ele alınmış; bu yaklaşıma öncülük eden Weber, Dilthey, Gadamer, Heiddegger, Schleiermacher gibi düşünürlerin bilim anlayışlarına ve yorumsamacı yaklaşıma katkılarına kısaca değinilmiştir. Yorumsamacı yaklaşımının pozitivist bilim anlayışına yönelttiği eleştiriler üzerinden iki bilim anlayışı karşılaştırılmış ve yorumsamacı yaklaşımın bilim anlayışı ortaya konmuştur. Bu düşünce doğrultusunda nitel araştırma ve onun doğası açıklanmıştır. Çalışmanın sosyal bilimlerin amaçlarına göre bir metodoloji arayan araştırmacılara yol göstermesi umulmaktadır.
\end{abstract}

Anahtar Kelimeler: Hermeneutik, pozitivizm, nitel araştırma, yorumlama, kültür.

\section{An Evaluation on the Relation between Hermeneutics and Qualitative Research}

\begin{abstract}
While social sciences, which are based on human beings and society, are dealt with scientifically, just like natural sciences, they are tried to be understood by using observations, comparisons, and experiments, spiritual factors (emotions, metaphysics, intelligence) are ignored. This paradigm, in which the interpretative narrative of social sciences takes place, tells us that human beings are a subjective entity, in the transformational process, people in all fields, including methodology, act together with the nature of social sciences. The aim of this study, which is dealt with theoretically, is to reveal the difference of the hermeneutical approach from the positivist understanding of science. In this context, the foundations and short history of the interpretative science approach are discussed; The contributions of thinkers such as Weber, Dilthey, Gadamer, Heidegger, Schleiermacher, who pioneered this approach, to the understanding of science and the interpretative approach were briefly mentioned. Based on the criticism of the interpretative approach towards the positivist understanding of science, two scientific conceptions were compared and the scientific understanding of the interpretative approach was revealed. In parallel with this thought, qualitative research and its nature were explained. It is hoped that the study will guide researchers looking for a methodology parallel to the goals of social sciences.
\end{abstract}

Key Words: Hermeneutics, positivism, qualitative research, interpretation, culture.

\footnotetext{
${ }^{1}$ Dr. Öğr. Üye., Süleyman Demirel Üniversitesi, iremaltintas@sdu.edu.tr, 0000-0002-3398-5366.

2 Yüksek lisans öğrencisi, cemilcanerdem1@gmail.com.
} 


\section{Giriş}

İnsanı ve toplumu esas alan sosyal bilimler, bilimsel boyutta ele alınırken tıpkı doğa bilimleri gibi gözlem, karşılaştırma ve deneyler kullanılarak anlaşılmaya çalışılmış, tinsel etkenler (duygular, metafizik, zeka) yok sayılmıştır. R. Carnap'ın dediği gibi, "bilim dolaysız deney üzerinde temellenen bir önermeler sistemidir” (Vergin, 2003, s. 158) Doğa bilimleriyle sosyal bilimlerin ortak bir mantığa sahip oldukları, hatta ortak bir metodolojik temele dayandıkları fikrine dayanan bu yaklaşım uyarınca esas olan "bilimin birliğidir" (Comte, 1986).

Doğa bilimlerinin etkisinde gelişen sosyal bilimlerde, ilk zamanlarda toplumsal olanın doğa bilimlerinin yöntemleriyle ele alınıp incelenebileceği savunulmuştur. Ancak zamanla toplumsal olanın kendine has nitelikleri olduğu ve doğa bilimlerinin yöntemleriyle incelenemeyeceği görüşü kabul edilmiştir. Çünkü doğa bilimlerinin yöntemleri toplumsal olanı anlama ve açıklamada doğru ve yeterli değildir. Böylece karşılaşılan sorunları ve yetersizlikleri gidermeye yönelik yeni bir bilimsel anlayış gelişmiştir. Yorumsal paradigma olarak da adlandırılan hermeneutik son dönemde araştırmalar için yönetici bir düşünce modeli olmaya başlamıştır (Mayring, 2011).

Kavramsal kökeni Antik Yunan'a uzanan hermeneutik yaklaşımının modern dönemdeki temelleri ise aydınlanma çağına rastlar. Sosyal bilimlerin bilimin tekliğinden kurtulmas1, kendine özgü yöntem ve tekniklerinin olması gerektiği anlayışının giderek ön plana çıkması yorumsamacı yaklaşıma yönelmeyi sağlamıştır. Çünkü insan edilgen ve mekanik bir varlık, bir makine, bir robot değildir; aksine aktif bir sistemdir;tüm eylem ve faaliyetleri ancak kültürel bağlamı içerisinde ele alındığında doğru anlaşılabilir. Bir başka deyişle insan davranışları içinde bulunduğu bağlama ve öznelliğe göre şekillenmektedir. Dolayısıyla sosyal bilimler nedensel bir açıklamaya değil; anlamaya dayalı, yorumsamacı bir açıklama anlayışını benimsemek durumundadır (Sunar, 1986).

Yorumsamacı yaklaşım, toplumsal gerçekliklerin doğru anlaşılabilmesi için bu gerçekliklerin bağlam içerisinde ele alınması ve art alandaki anlamlara odaklanılması gerektiği yönünde bir anlayış ortaya koyar. Bir başka deyişle hermeneutik yaklaşıma göre bireylerin ya da grupların eylemlerini, içinde gerçekleştiği toplumsal ve kültürel bağlamına dayalı olarak ele alıp yorumlamak gerekir. Çünkü insan eylemleri bir anlam dünyasının, belirli bir toplumsal sistemin, kültürel ögelerin ve çeşitli koşulların ortamında meydana gelir. Bilişsel bir varlık olan birey toplumun kültürü, tarihi ve diliyle yoğrularak sosyalleşir ve bir anlam dünyasına sahip olur. Davranışın doğru anlaşılması, ancak onun ardında yatan anlam dünyasının dikkate alınarak toplumsal ve kültürel bağlamı içerisinde yorumlanmasıyla mümkündür. Tüm hermeneutik geleneğin ve hatta daha erken düşünürlerin ifade ettiği gibi sosyal bilimin ele aldığı unsurlar birer nesne olmadığı gibi yaşam içinde oluşurlar. Dolayısıyla bu bilgi yine ait olduğu toprak içinde kendini bulur. Bu bağlamda hermeneutik anlamayı amaçlar ve bunun için de empati ve yansıtmayı içinde barındırır (Saygın, 2009).

\subsection{Araştırmanın Amacı}

Bu çalışmada yorumsamacı yaklaşımın bilim anlayışı ve nitel araştırma yöntemlerine nasıl temel oluşturduğu ele alınmıştır. Bu bağlamda aşağıdaki sorulara yanıt aranmıştır:

1. Yorumsamacı yaklaşımı oluşturan düşünsel ve tarihi temeller nelerdir?

2. Yorumsamacı yaklaşımın bilimsel yöntemi nedir?

3. Yorumsamacı yaklaşımın pozitivizme yönelttiği eleştiriler nelerdir? 


\section{Yöntem}

$\mathrm{Bu}$ çalışma, bir sosyal bilimci olarak hermenutik ve nitel araştırma yaklaşımlarına başka araştırmacıların bakış açısıyla ilgilenilmesi üzerine kurulmuştur. Dolayısıyla araştırma amaçlarına uygun olarak temel nitel araştırma modeline uygun olarak tasarlanmıştır (Glesne, 2013). Kullanılan literatür, yorumsamacı yaklaşımı nitel paradigma ile birleştirmeyi hedeflemiş ve kültürel araştırmaların, insan doğası ile ortak noktalarının nasıl ortaya çıktığını anlatmaya çalışmıştır. Bu sebeple temel nitel bir paradigma tercih edilmiştir.

\subsection{Pozitivist yaklaşıma göre insan}

Doğa biliminin hedefi, olguları matematiksel bir açıklama modeline uygun bir şekilde açıklayabilmektir. Buna göre doğa bilimi deneyim ve teorik akıl olarak çözümlenebilir. Doğa bilimcilerin bu basit anlatımı kavramlar ve nesneler arasında benzeşiklik yaratıldığını gösterebilir. Doğa bilimcilere göre tabiatın matematiksel bir yapısı vardı. Bilginin aklımızda oluşumu bile bu matematiksel formülün bir sonucu olarak görülmüştür.

Pozitivist bilim felsefesi doğa bilimleri ve toplum bilimleri şeklinde iki tür bilimden söz eder; ama toplum bilimleri esasında doğa bilimlerine göre hareket etmek zorundadır. Başka bir deyişle doğal ve toplumsal gerçeklik arsında obje farklılığına dayalı bir ayırım yapılmış olsa da bu bilimler tek bilim cinsinin türleridir (Comte, 1986). Pozitivist sosyal bilim anlayışı doğa bilimlerinin yöntemleriyle insan davranışlarının ve toplumsal olayların neden-sonuç ilişkisi içerisinde açıklanabileceğini, bunun sonucunda toplumsal olgularla ilgili evrensel bilgiye ve yasalara ulaşılabileceğini savunur. Pozitivizme göre saf ve gerçek bilgi, metafizik ögelerden arınmıs, rasyonel ve ampirik yolla elde edilen bilgidir (Hira, 2000). Ancak başta Max Weber ve Dilthey olmak üzere, pek çok düşünür pozitivizmin bilim anlayışını ve yöntemini reddederek, sosyal bilimlerin araştırma alanına toplumsal eylemi, kültürel olarak inşa edilen anlamı, değerleri ve öznelliği koymuştur (Aron, 1994).

\subsection{Yorumsamacı yaklaşımın ortaya çıkışı}

Yeniçağ, bilimlerin gelişmesi ilerlemesi olarak adlandırılabilecek bir çağdır. Filozoflar, bilgi sorununu metafizik, teolojik ve etik modellere bağlı kalmadan bilgi kuramını bağımsız bir felsefi disiplin olarak ortaya çıkarmışlardır. Bu, yeni çağın felsefi anlamda en önemli başarısıydı. Kant insanı merkeze alan kültürel kimliğinden ayrılmış bir bilgi öznesi olarak yeni bir akım başlattı. Kant, insan özgürlüğünü aklın otonomisi olarak keşfetmiştir. Ona göre insan, otonom olan aklının etkinliği ile bilgiyi elde edip eyleme geçer (Özlem, 1993). 20. yy'ın belli başlı felsefi akımları ile sürekli karşılaştırmalar yapan Gadamer'e göre yaşamın kendisi hermeneutik bir yapıya sahiptir. Tam da bu yüzden yaşama tin bilimleri temel olur (Özlem,1996). Tin bilimlerinde hermenuitiğin görevi, insanın tarihsel bir varlık olduğu vurgusundan hareketle tarihsel, toplumsal ve kültürel tini nesnelleşmiş, dişsallaştırılmış ifadelerden hareketle anlamaya çalışmaktır. Böylelikle hem bireysel bir yaşantı ve deneyimden hareketle tinin kendisi anlaşlacak hem de tinden hareketle deneyim anlaşılabilecektir (Öztürk, 2020).

Doğal gerçeklikler gibi toplumsal gerçekliklerin de insanlardan bağımsız olduğunu savunan pozitivist yaklaşımın tersine yorumsamacı paradigmaya göre toplumsal dünya, doğal olgular gibi ele alınamaz ve doğa bilimlerinin yöntemi ile incelenemezler. Çünkü toplum belirli bir yaşam tarzına, bu yaşam tarzı belirli bir kültürel sisteme dayanır. Doğa insanın dışında ve ondan bağımsız olarak var olurken insan yaşamı ve toplumsal olgular insan tarafindan toplumsal ve kültürel olarak inşa edilmiştir. Toplumsal yaşamı düzenleyen ilke, kural ve yasalar da evrensel nitelikte değildir, belirli bir kültürel ve sembolik sisteme özgüdür. Bu nedenle sosyal bilimler yasalara dayalı, nedensellik ilişkisini açıklamaya yönelik değil, anlamaya dayalı yorumsamacı bir yöntemi benimsemelidir (Creswell, 2016; Suğur, 2010; Şişman, 1998). 
Yorumsamacı (hermeneutik) yaklaşımın temelleri Antik Yunan'a dayandırılır. Antik dönemde Hermes, tanrıların mesajlarını insanlara, onların anlayabileceği şekilde açıklamaya ve yorumlamaya çalışmıştır. Ancak epistemolojik anlamda 19.yüzyılda gelişmeye başlamıştır (Göka, Topçuoğlu ve Aktay, 1999). Bilimsel bir anlayış olarak yorumsamacı yaklaşımı ilk savunan kişi ise ünlü Alman sosyolog ve düşünür Max Weber'dir. Toplumsal eylemi sosyolojik çalışmalarının merkezine alan ve anlamacı bir bilim anlayışı geliştirmeye çalışan Weber, yorumsamacı yaklaşımın en büyük savunucularından biridir. Weber'e göre insan davranışları ve toplumsal olgular doğa bilimlerinin açıklayıcı yöntemiyle değil, anlamacı ve yorumlamacı bir yöntemle ele alınıp incelenmelidir. Ancak yorumsamacı yaklaşımı sosyal bilimlere esas kazandıran kişi olarak Wilhelm Dilthey kabul edilmektedir. Onunla beraber hermeneutik bir anlama/yorumlama bilimi haline gelmiştir. Böylece doğa bilimleri ile toplum bilimleri birbirinden ayrılmış ve farklılaşmıştır (Kaya, 2019). Zira kültür insanın tarihsel alanda var olduğunu gösterir. Başka bir deyişle insanın olduğu yerde dil, din, gelenekler ve topluma ait yaşantı bulunmaktadır. İnsan, toplumsal varlığını bu üçgende kanıtlamaktadır.

Sosyal bilimleri kendisine özgü bir yöntem temelinde kurmaya çalışan Dilthey doğa bilimlerini, açıklamaya yönelik bilimler;sosyal bilimleri ise anlamaya dayalı yönelik bilimler olarak nitelemektedir. Bu doğrultuda yöntemsel bakımdan anlamayı sosyal bilimlerin temeline koymaktadır (Akın, 2005). Dil, duygu ve düşüncelerin aktarıldığı, iletişimsel bir dizgedir; bu duygu ve düşünceler bütünü kültürden etkilenir ve dile yansır. Haliyle dil içerisinde bu kültür yapılarının izini sürmek mümkündür. Dil, insanların yazılı ya da sözlü söylemleri, bu hususiyetiyle kültürün en doğal ve önemli taşıyıcısı ve aktarıcısıdır (Ünveren Kapanadze, 2019). Bu bağlamda Dilthey, insanın yaşantılarıyla ve oluşturduğu kültürüyle içinde bulunduğu karmaşık yapıya ait bilgilerin anlamlandırılmasının ampirik yollarla yapılamayacağını savunmuştur. Kavramların sadece filolojik yapısı değil bu kavramların içinde bulunduğu bağlama bakmak gerekir. Dilthey'e göre, bu yapıldığı zaman ancak, söz konusu anlamlar sayesinde o dönem ya da çağa egemen olan tinsellik kavranabilir. Bu anlamları açığa çıkaracak olan yöntem de, bir tür anlama ve yorumlama sanatı olarak, hermeneutiktir (Cevizci, 2005). "Dilthey'e göre insan, var olduğu sürece, her şeyi anlamaya çalışır, bu da insanın her şeyi yorumlaması demektir." Zira anlamak yorumlamaktır. Bununla birlikte anlama, tek taraflı olmaz, çünkü anlamak aynı zamanda anlaşılmayı da gerektirir. "Bu anlam olgusu da tarih bilinciyle birleşerek kültürü oluşturur." Kültür de sosyal bilimlerinin ortaya çıkıp gelişmesinde oldukça önemli bir unsurdur (Dilthey, 2011).

Dilthey'e göre tinsel dünya bir olgu dünyası, bir ampirik gerçeklik alanı değil, bir anlam dünyasıdır. Ona göre doğa bilimleri için ampirik sonuçlar yeterli olmaktadır, ancak sosyal bilimlerde insan ile ilgili olan her şeyi hesaba katmak gerekir: kültür, toplumsal yap1, yaşant1, toplumsal statü, empati, sempati, algılama, sezgi gibi. Anlama olgusu da bu noktada devreye girmektedir. Zira anlamak için birey kendi benliğini aşarak diğer kişileri de içerden yaşamalıdır. Dilthey'e göre bu bir zorunluluktur (Özlem, 1993). İnsanın karmaşık olan dünyasını, oluşturduğu tarihi ve kültürü anlamada Dilthey dışında karşımıza çıkan üç isim Schleiermacher, Heidegger ve Gadamer'dir.

Schleiermacher çalışmalarında hermeneutiği, tüm metinlere uygulanabilecek bir anlama ve açıklama yöntemi olarak tasarlamıştır. O, modern hermeneutiğin temel kavramı olan dili bir araç değil, anlaşılması gereken bir varlık olarak vurgulamıştır (Bingöl, 2019). Modern hermeneutik, başlarda aydınlanma düşüncesinin genel özelliklerini benimser. Rasyonelliği esas alır ve geleneksellik karşıtı olarak konumlanır. Ancak Schleiermacher onu bu anlayıştan kurtarmaya çalışır (Fırıncıoğulları, 2016). Schleiermacher'in düşünceleri, yaşadığ dönemin romantik akımından etkilenmiştir. Romantik hermeneutik anlayışına göre, yorum yapan kişi, ilk olarak metnin yazıldığı dönem ve yazarın kullandığı dil hakkında bilgi edinmelidir; çünkü eserin ortaya çıktığı dönemdeki toplumsal ortam, dönemin koşulları ve aynı zamanda yazarın yapıtı ortaya koyarken kendi iç dünyasında neler yaşadığı bilinmelidir 
(Toprak, 2003). Doğa bilimsel bir hakikat iddiasının meşruiyet kazandırılmamış olduğu dönemlerde, romantik gelenek içerisinde hermenuitik empatinin fazla olduğu, uzlaşmaya varmanın kolay olmadığı alanlardaki mesafeyi aşmanın garantisi olarak yer almaktaydı. Öte yandan insani tecrübeyi anlamada da bir rol üstlenmektedir. Esasında bu durum Schleiermacher'in başarıs1 olarak nitelenmektedir (Öztürk, 2020).

Hermeneutik yaklaşıma büyük katkıları olan düşünürlerden biri de Heidegger'dir. Zira bu yaklaşım Heidegger'le birlikte yeni bir boyuta geçmiştir. O, geleneksel hermeneutikçilerin yapmaya çalıştı̆̆1 tarzdaki gibi bir yaşam felsefesi kurma ya da yöntemsel bir arayışın içerisinde değildir. Hermeneutiği insan varlığının açıklamasına yönelik olarak ele almıştır (Bingöl, 2019). Buna anlamanın ontolojik temelleri de diyebiliriz. Bu anlayış, olağanüstü bir başarıdan ziyade bir gereksinim olarak düşünülmelidir (Bauman, 2017).

Heiddegger'in öğrencisi olan Gadamer ise hermeneutiği ontolojik alanına kaydırır. Gadamer'e göre insan var olduğu andan itibaren dünyayı anlamlandırmaya başlamaktadır. Anlamak ya da anlamlandırmak ise yorumlamaktır (Fırıncığulları, 2016, s. 46). Gadamer bireyin anlamlandırmasında kültürü, yaşantıları ve bireyin psikolojik süreçlerini de içine katar. Thomas Wilson'in 1970'lerde dile getirdiği hermeneutik öncelikle sembolik iletişim kuramından etnometodolojiden etkilenmiştir. Bu kuramın temel düşüncesi, insanın artık körü körüne yerleşik kültürel normlara göre davranmadıkları aksine her etkileşimin yorumlayıcı bir süreç olduğudur (Mayring, 2011). Dolayısıyla insanın temel bağlamda birtakım algılarını konuşan kişinin kültürünü (bu sürece en çok dildeki yorumsal anlam dahildir) ve günlük hayatını yansıtmaktadır.

\subsection{Hermenetuiğin nitel araştırmaya yansımaları}

Tarihselci bilim felsefesi, insana yönelecek bir bilimin, pozitivist model dişında bir modele yönelmesini vurgular. Bu yüzden tek bir cinse bağlı iki tür bilim değil iki ayrı cinse bağlı bilimler vardır. Çünkü tarihsel ve toplumsal gerçeklik insanı bir meta olarak görmez bir amaç-eylem bağıntısına göre oluşan, insanın kendisi kurup yine kendisini içine aldığı bir alan vardır. Bu alan tinsel bir alandır. Bilimin pozitivist bilim felsefesinden ayrıldığı tinsel bilim, istatistiksel yöntemlerle gerçeklik hakkında kapsamlı bilgilere ulaşmak konusunda bize oldukça kısır bir bilgi sunmaktadır. Ayrıca olguların temel nedenleri hakkında net bir bilgiye erişmemize olanak sağlamaz. Oysa gerçek bilme, nedenleri çözümlemek söylem ve dil üzerinden yöntemleri ortaya koymakla gerçekleşir (Özlem,1996). Dil pratikleri; sosyal gerçekliğin inşasında, eylemlerin ve davranışların meydana getirilmesinde, kısaca her yerde ve alabildiğine dinamiktir. Bu davranışlar bütünü kültür olgusu bağlamında değerlendirilir. Hâliyle davranışa şekil veren, onu oluşturan yapının dil eyleminin olması bu anlamda kültür ve söylemin yaratımında dilin etkinliğini ortaya koyan bir diğer dikkat çekici durumdur (Ünveren, 2020). Bu düşünceye paralel olarak Kuhn da bilimsel araştırma anlayışını genellikle bütünüyle izole edilmiş bireyin aklına, algısına ve tecrübesine göre tanımlamıştır (Barnes, 2008). Bu durumda bilme ediminin doğruluğu kişiye göre değişiklik gösterir.

Hermeneutiğin bağlam olarak ele alındığı bu çalışmada, araştırma probleminin yorumlayıcı bir yaklaşımla izlenebileceği düşüncesinden yola çıkılmıştır (Patton, 2014). Nitel yöntemin altında yatan yorumlayıc1 paradigma sosyal bilimlerde gücünü giderek arttırmaktadır. Nitel yöntemle tasarlanmış bir araştırmada tıpkı hermeneutik gibi derin bir kavrayışa ulaşma çabası vardır (Karataş, 2017). Nitel araştırmalar hermeneutiğe uygun olarak kişiye özgü bir bakış açısı içerir ve bu da araştırmacının kendi potansiyelini göstermesi anlamına gelir. Dünyayı ve sosyal olguları inceler ve araştırmacının bakış açısından bir yorumlama elde edilmesine sağlar. Özellikle sosyal olay ve olguların karşısında tutum ve davranışlarının ana sebepleri, sosyal grupların nasıl iletişim kurduğu ile yakından ilgilenir (Baltac1, 2019). 
Sosyal bir araştırmada yorumlama, araştırmacının öğrendiklerinin ve perspektifinin bir açıklamasıyla veya önceki araştırma deneyimlerinden elde ettiklerinin şekillenmesiyle ilgilidir (Gubrium ve Holstein, 1997). Böylelikle nitel araştırmanın önem verdiği noktalar hermeneutik ile aynı doğrultudadır. Bunlar; özneye ilişkinlik, öznenin betimlenmesi ve yorumlanması, öznenin kendi doğal ortamında araştırılması, sonuç çıkarılmasında genelleștirme sürecinin anlaşılması olarak sıralanabilir (Mayring, 2011, s. 16). Salt pozitivist (nicel) düşünme 21. yy.'da şüpheyle karşılanmaktadır. Bunun sebebi nicel araştırmaların insanı anlamak yerine onları test eden, ölçen veya konuyla ilgili deney -hesap yapan bir yaklaşım sergilemesidir. Yorumbilim olarak da adlandırılan nitel araştırma asıl amaca dikkat çeker yorumlayıcı bir anlayış veya anlam için kuramsal bir çerçeveyi önümüze getirir (Patton, 2014). Nitel araştırma gerçek hayattaki durumların sözlü bir açıklaması olarak yorumlanır. Nicel araştırmalar çalışılan ortam ile hiçbir bağlantı kurmadan bir problemi hızlıca tespit edip çözümlemeye yöneliktir (Silverman, 2018). 1970'li yıllardan itibaren nitel araştırma tek başına kullanılmaya başlanmıştır ve nesneyi tanımlama konusunda nicel araştırmaya göre daha yeterli olması açısından daha üstün olduğu söylenebilir (Giddens ve Sutton, 2014; Patton, 2014; Silverman, 2018).

$\mathrm{Bu}$ durumları açıklamada nitel araştırma metodolojisi farklı desenler ve veri toplama araçları geliştirirler. Bu geliştirme nitel araştırmanın doğasına bağlı olarak araştırmacının kendi bilgi ve deneyimleri ile doğrudan ilgilidir.

Nitel araştırmanın öznel doğası, hermenutiğin öznel doğasıyla uyumludur. Buna göre bir araştırmacının araştırmayı ikinci, üçüncü araştırmacılar gözünden yürütmesi söz konusu değildir (Peshkin, 2000). Süreç içinde bu değişimin sağlanması sosyal bilimin özünden kaynaklanmaktadır (Özdemir, 2010).

Sürekli yaratılmakta olan argüman, hikaye, anlatı ile ilgili olarak öğrenilenlerin önemi, düzeni ve biçimi algılamayı gerektirir. Peshkin (2000)'in problematik adını verdiği bu durum araştırmacı öznelliğinin ve yorumlamanın kesişimi olarak tanımlanır. Problematikle ilgili fikirler üzerine bir dizi üst analizsel düşünceler sunulması gerekir. Araştırmacının çalışmasında sunduğu tezler doğrudan veya dolaylı olarak kendisinin düşünme beceriyle ilgilidir. Buna araştırmacının becerisini dersek yanlış bir şey söylemiş olmayız. Araştırmacı ne kadar çok iç görüye sahip ise o kadar fazla bakış açısına sahip olur ve bu iç görüyü araştırmasında kullanır.

\section{Sonuc}

İnsani gerçekliğe ilişkin bilimler kültür bilimleri olarak adlandırılır. Bu bilimler, evrimleri boyunca insanların yarattığı sanat eserleri dışında yasalar, kurumlar, siyasal rejimler, dinsel deneyler ve bilimsel kuramları anlamaya ve açıklamaya çalışırlar (Aron, 1994). $\mathrm{Bu}$ doğrultuda Weberci kuram bireyi anlamak için yeni bir metodoloji geliştirilmesini mümkün kılmaktadır. Hermeneutik yaklaşım kendi kendini yansıtıcı bir öğrenme süreci olarak araştırmacı ile araştırılan birey arasında iletişimsel anlamayı esas kılmaktadır. Bu amaçla; görüşmeler mektuplar ve özyaşam öyküleri ile anlatısal görüşmeler kullanılmaktadır. Foucault (2017) deneyimlerin öznel olduğunu ve başkaları tarafından yorumlanmasının güç olduğunu söyler. Bu tespitini kendilik kavramıla birleştirir. Ona göre kendilik kelimesi insanın özne olarak sahip olabildiği ve görüştüğü ilişki biçimidir (Foucault, 2017). Örneğin kişi bir kentte politik özne olabilir. Bu amaçla oy veren ya da diğerlerini sömüren vb. anlamlar yükler. Bu durumda kendilik özne olarak bu insanın politik bir ilişki içinde kendi kendisine sürdürdüğü bir biçim olacaktır. Dil, eylem ve işlev yönünde bir aracıdır, bu noktada insanlar dili niyetli bir şekilde, belli amaçlara yönelik olarak kullanırlar ve bu etkin kurgu süreci, belirli bir sosyo-kültürel bağlamda kişilerin anlama, algılama, anlamlandırma ve yorumlama süreçlerine koşut olarak, dilde çeşitlilik şeklinde söylemlere yansır (Ünveren Kapanadze, 2019). İnsanlar kültürel sistemlerine, anlam dünyalarına ve yaşam koşullarına bağlı olarak 
toplumsal gerçeklikleri birbirinden farklı şekilde deneyimler, tanımlar ve anlamlandırır. Toplumsal olgular durağan ve evrensel değildir, bağlamları içerisinde birbirlerinden farklı biçimlerde gelişirler. Dolayısıyla toplumsal olgular için evrensel ve sabit kurallar ya da yasalar yoktur.

Hermeneutik yaklaşım bu yönüyle pozitivizmden ayrılır. Hatta zaman zaman yorumlayıcı paradigmayı savunan sosyologlar pozitivizmin getirdiği nicel araştırmaların gerçek dünyayı açıklamak, anlamak ve yorumlamak için yeterli olmadığı görüşünü savunurlar. Sosyal bilimlerin bu yorumlayıcı doğasına, bireylerin tikel ya da grup olarak dünyayı anlamlandırmalarına yardımcı olmak için nitel araştırmaların gerekliğine 1970'li yıllardan (nicel araştırmalara gerek olmadan) inanmaya başlamıştır. Bir adım ötede hermeneutik, pozitivist yaklaşımın kaygılarından ve terminolojisinden uzak olduğunda sosyal bilimin doğasında daha da hâkim bir durumda olabilecektir (Saygın, 2009).

Yeni metodoloji, nicel araştırmayla ölçüleni artık kavramsal düzeyde de olsa anlamaya çalışmaktadır. Nitel araştırmanın bu anlama çabası, geniş ölçüde tutarlı ve uyumlu küçük ölçekli grupların anlaşılmaya çalışılmalıdır. Başka bir deyişle, gerçek dünyayı anlamlandırmada güvenilir, tutarlı ve doğru bilgiler kazandırmanın önemli olduğu görüşü hâkimdir (Bogdan \& Biklen, 1997; Patton, 2014; Silverman, 2018).

Toplumsal olguların kendine özgü yöntemlerle incelenmesi gerektiğini savunan yorumsamacı bilim anlayışına göre insan eylemleri ve toplumsal gerçeklikler toplumsal ve kültürel bağlamı içerisinde ve olabildiğince kapsamlı bir şekilde anlamak amacıyla ele alınıp incelenmelidir. Bu bağlamda insanların toplumsal dünyayı nasıl algıladıklarını, anladıklarını, deneyimlediklerini, yorumladıklarını ve ürettiklerini anlamaya önem verir. Yorumsamacı bilim anlayışının bu yaklaşımı doğrultusunda nitel araştırma yöntemleri geliştirilmiştir. Bu yöntemlere görüşme, odak grup çalışması, katılımlı gözlem, vaka çalışması, içerik analizi, etnografi gibi yöntemler örnek verilebilir. Bu yöntemler insan eylem ve etkileşimlerine odaklanır. Çünkü toplumsal gerçekliklerin insan eylem ve etkileşimleri ile inşa edildiğini; gerçekliği anlamak için bu eylem ve etkileşimlere odaklanmak gerektiğini savunur.

\section{Kaynakça}

Akın, M. H. (2005). Sosyal bilimlerde yöntem sorunu olarak anlama ve açıklamanın sinırları. (Yüksek Lisans Tezi ), Selçuk Üniversitesi Konya

Aron, R. (1994). Sosyolojik düşüncenin evreleri (Ç. K. Alemdar, Çev.). Ankara: Bilgi.

Baltac1, A. (2019). Nitel Araştırma Süreci: Nitel Bir Araştırma Nasıl Yapılır? Ahi Evran Üniversitesi Sosyal Bilimler Enstitüsü Dergisi, 5(2), 368-388.

Barnes, B. (2008). T.S. Kuhn ve Sosyal Bilimler (Ç. H. Aslan, Çev.). Ankara: Paradigma

Bauman, Z. (2017). Hermenötik ve sosyal bilimler (Ç. H. Oruç, Çev.). İstanbul: Ayrıntı Yayınlar1.

Bingöl, U. (2019). Felsefi hermeneutik ve serseri şiirinin felsefi hermeneutik açısından yorumlama denemesi. Siirt Üniversitesi Sosyal Bilimler Enstitüsü Dergisi, 7(13), 94115.

Bogdan, R., ve Biklen, S. K. (1997). Qualitative research for education. Allyn \& Bacon: Boston, MA.

Cevizci, A. (2005). Paradigma felsefe sözlüğü. İstanbul: Paradigma

Comte, A. (1986). Pozitivizm ilmihali (P. Erman, Çev.). Ankara: Milli Eğitim Gençlik ve Spor Bakanlığ1. 
Creswell, J. W. (2016). Qualitative inquiry and research design: Choosing among five approaches. Los Angeles: Sage publications.

Dilthey, W. (2011). Hermeneutik ve tin bilimleri: Notos Kitap Yayınc1lı Eğitim Danışmanlık ve Sanal Hizmetler Tic. Ltd. Şti.

Firıncıoğulları, S. (2016). Sosyal bilimler ve hermeneutik üzerine kısa bir değerlendirme. Sosyoloji Dergisi(33), 37-48.

Foucault, M. (2017). Hermenötiğin Kökeni, Kendilik Hakkında-Dartmouth Konferanslarn 1980 (Ş. Ç. Solmaz, Çev.). İstanbul: Ayrıntı.

Giddens, A., ve Sutton, P. W. (2014). Sosyolojide temel kavramlar (Ç. A. Esgin, Çev.). Ankara: Phoenix

Glesne, C. (2013). Nitel araştırmaya giriş (A. Ersoy \& P. Yalçınoğlu, Çev.). Ankara Anı

Göka, E. ve Topçuoğlu, A., \& Aktay, Y. (1999). Önce söZ vardı: yorumsamactlı üzerine bir deneme. Ankara: Vadi

Gubrium, J. F., \& Holstein, J. A. (1997). The new language of qualitative method: Oxford University Press on Demand.

Hira, İ. (2000). Sosyal Bilimler: Yasa koyucu tasarımdan yorumcu tasarıma. Bilgi, 2, 81-96.

Karataş, Z. (2017). Sosyal bilim araştırmalarında paradigma değişimi: Nitel yaklaşımın yükselişi. Türkiye Sosyal Hizmet Araştırmaları Dergisi, 1(1), 68-86.

Kaya, F. (2019). Yorumsamacı Yaklaşımda Anlama Kavramının Önemi ve Pozitivizm Eleştirisi. Dicle Üniversitesi Sosyal Bilimler Enstitüsü Dergisi, 22, 276-280.

Mayring, P. (2011). Nitel Sosyal Araştırmaya Giriş (A. Gümüş \& S. M. Durgun, Çev.). İstabul Bilgesu

Özdemir, M. (2010). Nitel veri analizi: Sosyal bilimlerde yöntembilim sorunsalı üzerine bir çalışma. . Eskişehir Osmangazi Üniversitesi Sosyal Bilimler Dergisi,, 11(1), 323-343.

Özlem, D. (1993). Felsefe yazıları. Ankara: Anahtar Kitaplar

Özlem, D. (1996). Metinlerle hermeneutik (yorumbilgisi) dersleri. İstanbul İnkılap

Öztürk, E. (2020). Hermeneutiğin Öyküsü:gadamer Odaklı Bir Analiz. Ankara: An1.

Patton. (2014). Nitel araştırma ve değerlendirme yöntemleri (S. B. Demir, Çev.). Ankara Pegem Akademi

Peshkin, A. (2000). The nature of interpretstion in qualitative research. Educational researcher, 29(9), 5-9.

Saygın, T. (2009). Sosyal Bilimlerin Doğası ve Hermeneutik Paper presented at the Altınc1 Ulusal Sosyoloji Kongresi, Aydın

Silverman, D. (2018). Nitel verileri yorumlama (E. Dinç, Çev.). Ankara Pegem Akademi

Suğur, N. (2010). Sosyolojide araştırma yöntem ve teknikleri. Eskişehir: Anadolu Üniversitesi.

Sunar, İ. (1986). Düşün ve toplum. Ankara: Birey ve Toplum

Şişman, M. (1998). Eğitim Yönetiminde Kuram ve Araştırmada Alternatif Paradigma ve Yaklaşımlar. Paper presented at the VII. Ulusal Eğitim Bilimleri Kongresi, Konya.

Toprak, M. (2003). Hermeneutik (yorum bilgisi) ve edebiyat. İstanbul: Bulut 
Ünveren Kapanadze, D. (2019). Bağlam ve süreç temelli yazma becerisinin gelişiminde söylem çözümleme yönteminin etkisi: örnek uygulama. YYÜ Eğitim Fakültesi Dergisi (YYU Journal of Education Faculty); 16(1):202-242.

Ünveren Kapanadze, D. (2019). Türkçe öğretiminde anlama becerisinin gelişiminde kültürel bağlamda bir yöntem önerisi: Salur Kazan'ın Evinin Yağmalanması örneği. Atatürk Üniversitesi Sosyal Bilimler Enstitüsü Dergisi, 23(1): 289-310

Ünveren, D. (2020). Türkçe öğretiminde aşkın bir millî kimlik alanı: Salur Kazan'ın Evinin Yağmalandığı Destan. Dil ve Edebiyat Araştırmaları (DEA), Bahar, (21) 175-199

Vergin, N. (2003). Siyasetin sosyolojisi. İstanbul: Bağlam. 